\title{
Portfolio assessment as a problem based learning model to help elementary school
}

\section{students' deal with Mathematics}

\author{
Isnawati ${ }^{1^{*}}$ \\ Dwi Yulianti ${ }^{2}$ \\ Siti Samhati ${ }^{3}$ \\ ${ }^{1,2,3}$ Postgraduate Program, University of Lampung, Bandar Lampung, Indonesia
}

\begin{abstract}
The concern in this study is children's inability to solve primary school math problems, with a goal to establish how students' capacity to solve mathematical problems in primary school and to describe the best method or learning model for delivering materials for the circumference and area of parallelograms and triangles using a problem-based learning model with portfolio assessment. This studi is qualitative in nature, employing a total of 30 elementary school chosen through a random sampling technique. The results showed that the problem based learning model based on the portfolio assessment was suitable for use in elementary school mathematics learning compared to conventional learning approaches because students were more active in participating in learning and the teacher was only a facilitator.
\end{abstract}

\section{KEYWORDS}

Problem-based learning, portfolio assessment, problem solving skill

Received: 2 August 2021

Accepted: 13 August 2021

Published: 16 August 2021

\section{Introduction}

Many teachers in elementary schools complain about their students' low ability in solving math problems. Mathematics plays an important role in every subject. It is a discipline that uses the human intellect to build estimating, calculating, counting, sketching, and measuring skills in order to solve problems in everyday life that are influenced by the environment (Altun, 2013). According to Liberna (2012) mathematics is generally one of the subjects that are not liked by some students where they consider mathematics as a subject that is not easy to understand because there are too many formulas that must be memorized and complicated questions, while students on the other hand also try to avoid these difficulties. Wahyudi, Heruman (2007) argues that "mathematics is a science that studies abstract structures and has patterns of relationships in them". Begle (1979) suggests four kinds of mathematical objects consisting of facts, concepts, operations, and principles. Mathematics related to abstract ideas is given symbols that are arranged hierarchically with deductive reasoning which thus makes learning mathematics a highly mental activity. Hasratuddin (2019) explained that Mathematics has the capacity to supply a wide range of abilities and attitudes that humans require in order to live intelligently (intelligently) in their surroundings.

Branca (1980) suggests that the ability of problems solving is the heart of mathematics. Based on the principles and standards of school mathematics, problem-solving can be said to be one of the necessary parts to complete mathematics learning. In other words, problem-solving also aims to improve creative, logical, critical, and systematic thinking so that students, in this case, must of course master a series of problem-solving in mathematics. According to Polya (Astriyani, 2016), there are four steps to solving mathematical problems as follows: (1) understanding the problem, (2) making a problem-solving plan, (3) carrying out problem-solving, and (4) seeing (checking) again. Polya (Wardani, 2009: 3) explains "problem-solving as an attempt to find a way out of difficulties to achieve a goal whose solution cannot simply be found". Problem-solving is the process of selecting and executing effective and useful tools and behaviors to overcome the obstacles that an individual must overcome in order to achieve his or her goals (Bingham, 2004; Duman, 2013). According to Obodo (2004), The problem-solving technique entails recognizing and selecting mathematical issues that arise from particular students' experiences, presenting these problems to them, and guiding them through their solutions. Solving math problems is an important part of mathematics that is becoming a requirement in all mathematics curricula around the world (Liljedahl, Trigo \& Malaspina, 2016). Beige emphasizes the importance of problem-solving (Surya, Putri, and Mukhtar, 2017) as he stated that students can learn about increasing their comprehension of mathematical principles through problem-solving by 
working through specific situations using mathematical applications for real-world problems. Polya (1954) claims that pupils can solve an issue if they follow the procedures including: (1) recognize the issue, (2) create a plan, (3) carry out the plan, and (4) perform a recheck. Along with the importance of solving mathematical problems in mathematics education, educators must certainly strive so that students can achieve optimal results in mastering problem-solving. Duong (2016) explains that problem-solving efficiency is predicated on being influenced by academic learning. Various efforts can be done by the teacher. Some of them are by providing good learning media or appropriate teaching methods for students. The right learning model can encourage students to be more active and able to solve problems well. Against this background, the researcher used the PBL method. PBL is learning that uses real-world problems as a context for students to learn critical thinking and master problem-solving skills, and to acquire knowledge and important concepts from knowledge. According to Barber et al. (2015), some of the characteristics of PBL are the use of real-world problems and working in groups. One of the learnings related to the PBL model is learning with authentic assessment. Authentic assessment allows teachers to evaluate student's performance and abilities based on reality or origin. This is an effective strategy to increase student involvement in learning, creativity, and self-confidence (Hodgman, 2014).

Assessment is very important in the learning process. The 2013 curriculum, therefore, places great emphasis on authentic assessment. Clements and Cord (Crisp, 2016) explain that assessment is an important component in learning and the learning environment because of its role in knowing learning outcomes. For teachers to be able to infer the meaning of a mathematical understanding, an authentic assessment is critical in this problem-solving exercise (Romberg \& Wilson, 1995).

The researcher uses a problem-based learning model based on portfolio assessment in solving mathematical problems in elementary schools. Portfolio assessment is a system of collecting student works that are analyzed to show student progress following instructional goals (Valencia, 1991). As an assessment instrument, portfolios are focused on documents about productive student work, namely "evidence" about what students can do, not what students cannot do (answer or solve) (Depdiknas, 2003). In other words, what students include in their portfolios are things that students understand. A portfolio can be used by teachers to show parents evidence of student progress, achievements, skills, and student attitudes (Trianto, 2009).

According to Santrock (2008), four groups of evidence can be placed in a portfolio, namely; artifacts, reproductions, work authorization, and production. Tabatabaei \& Assefi (2012) states "Among all the procedures of alternative assessment, the portfolio has become a popular technique currently". Among all alternative valuation procedures, portfolio assessment has become a popular technique today. Based on this, it is known that authentic assessment in the form of a portfolio is associated with problem-solving abilities. This is based on the fact that with a portfolio, students can review the assignments given by the teacher so that when they forget one material, they can easily open the collection of assignments. In this way, it will be easier for students to practice problem-solving skills.

\section{Research method}

The study adopted a qualitative approach. The population in this study were fourth grade elementary school students in the Ki Hajar Dewantara 2 teacher working group located in the Negara Batin sub-district of 134 students. Meanwhile, the sample used was taken through a random sampling technique or using a random sample of fourth grade students in the Ki Hajar Dewantara 2 elementary school working group, Negara Batin Sub District, with a total of 30 students. The researchers chose the purposive sampling technique because it was simple to obtain information from participants that was easily available to them (Senol, 2020). The data collection technique used was interviews and questionnaires. Data analysis was carried out with reference to qualitative data analysis techniques. This is an analysis of data sourced from data collected from the interview process and giving questionnaires to people related to what will be researched.

\section{Results and discussion}

Elementary school pupils' ability to solve mathematical problems is a high-order thinking talent. Researchers are interested in investigating about the differences in students' mathematical problem-solving abilities between those who use PBL-based learning models based on portofolio assessments and those who use traditional learning.

Based on the results of data collection through interviews with 6 elementary school teachers who teach in related elementary schools, it was found that there were problems in the form of the low ability of students to solve math problems. The right solution to overcome these problems is therefore very much needed. One effort to overcome this is by choosing a method or strategy that is appropriate to the problem at hand. In the opinion of the teachers who have been interviewed, almost all of them have the same opinion where students tend to be less active if given lessons using a conventional approach. This is because this approach is teacher-centered. However, if students are taught using a problem-based learning approach which is a learning approach that seeks problems that occur in the real world, students will be trained to think more critically, be active, and find solutions. This is following the opinion of Nurhadi (2004) which defines that "Problem-Based Learning (Problem-Based Learning) is a teaching approach that uses real-world problems as a context for students to learn about critical thinking and problem-solving skills. In essence, the PBL learning model based on the portfolio assessment is the right method used to solve a math problem in elementary school. Sears, S.J. and Susan B. Hers suggested the characteristics of problem-based learning as follows: 
Engagement, which includes several things such as: Preparing students to be able to act as self-directed problem solvers who can collaborate with other parties, confronting participants students in a situation that encourages them to find problems, examine the nature of the problems at hand while making assumptions, planning solutions, and so on. Students who have high abilities in the process of understanding the material in PBL can help students with low abilities considering they are both involved in one group. This shows that learning the PBL model based on portfolio assessment makes a good contribution to understanding the material being studied.

PBL is learning, authentic inquiry, collaboration, and efforts to produce works and demonstrations so that learning does not only focus on acquisition using unstructured and open-ended authentic problems but also simultaneously developing problem-solving skills and critical thinking and building new knowledge. Concerning the nature and steps of this PBL. Aisyah (2011) mentions the advantages of the PBL model are as follows: 1) enables students to become technology literate, equips students with the skills and confidence to succeed in global competition, and also teaches the core curriculum in an interdisciplinary manner. 2) Improving the quality of learning, changing teaching patterns from "telling" to "doing", providing opportunities for students to learn according to their interests and making their own decisions, and providing opportunities for students to discuss how they will find answers to questions or solve problems. 3) Creating conditions for students to be active. 4) Explore students' creativity in solving problems. However, PBL also has weaknesses, especially the time required to complete one learning cycle which takes a long time. Based on the nature of Mathematics related to the characteristics of Mathematics learning as described above, the PBL learning model can be used as an alternative model for learning Mathematics in elementary schools. The theoretical implementation of the PBL learning model can improve the competence of students' mathematical problem-solving process skills which will have an impact on the mastery of mathematical concepts. Various action studies prove the potential of PBL empirically. Siswantara, Manuaba \& Meter (2013) conducted a study on the application of the Problem Based Learning model at SD Negeri 8 Kesiman and found results that the Problem Based Learning model was effectively able to improve science learning activities and outcomes. Wulandari, Budi \& Suryandari (2013) conducted a CAR and found the results that the application of the PBL Model could improve the process and learning outcomes of science for fifth graders at SD Negeri Mudal Purworejo. Apriani, Riska (2013) reported the results of the study as follows: a) the use of the Problem Based Learning Model can improve teacher performance, b) the activities of the fourth-grade students of SD Negeri Randugunting 3, Tegal City and student learning outcomes in science subjects. Lohman \& Finkelstein (2002) conducted a study entitled "Designing Cased in Problem Learning to Foster Problem Solving Skills" and reported that the Problem Based Learning model was found to be effective for improving problem-solving skills. Perliawan Franjaya, conducted research entitled "Application of Authentic Assessment in the Form of Portfolios in Problem-Based Learning to Improve Students' Mathematical Problem Solving Ability". After collecting data through interviews and questionnaires, it was found that the problem learning model based on the Fortopolio assessment was stated to be able to improve the ability to solve mathematical problems in elementary schools. (Letitiva) a child's ability is influenced by the ability to solve problems and exchange information with others who are more aware of it which will make the information obtained clearer.

\section{Conclusion}

Based on the results of interviews with teachers and the results of distributing questionnaires to students that have been carried out, it is known that the learning carried out has not used the PBL learning model based on the Fortopolio assessment, but still uses conventional learning models or traditional methods. This is one of the causes of students tend to be less active in learning so that the ability to solve mathematical problems is also low because of teacher-centered learning. Selection of the right model is therefore very necessary to improve students' mathematical problem-solving skills. One of the suggested and effective models to improve the mathematical problem-solving ability of elementary school students is to use a portfolio-based learning model.

\section{References}

A., Branca N. (1980). Problem solving as a goal, process, and basic skills in problem solving mathematics: 1980 yearbook edited by S. Krulik and R.E Reys. Reston, VA: NCTM.

Aisyah, (2011). Perbedaan problem based learning dan problem solving. http://susantojk.blogspot.com/2011/07/problem-based-learning-dan-problem.html. Diakses tanggal 11 Agustus 2014.

Altun, M. (2013). Eğitim fakülteleri ve sınıf öğretmenleri için matematik öğretimi (Mathematics teaching for faculties of education and teachers). Bursa: Aktüel Alfa.

Apriani,Riska. (2013). Peningkatan pembelajaran perubahan lingkungan melaui model problem based learning pada siswa kelas IV Sekolah Dasar Negeri Randugunting 3 Kota Tegal. Skripsi: UNNES Semarang Tidak diterbitkan.

Astriyani, Arlin. (2016). Peningkatan kemampuan pemecahan masalah peserta didik dengan penerapan model pembelajaran problem possing. FIBONACCI: Jurnal Pendidikan Matematika dan Matematika. 2(1). 21-30.

Barber., Wendy., King., Sherry., Buchanan., \& Sylvia. (2015). Problem based learning and authentic assessment in digital pedagogy: embracing the role of collaborative communities. Electronic Journal of e-Learning. 13(2), 59-67.

Begle, E. G. (1979). Critical variables in mathematics education. Washington D.C: The Mathematical Association of America and NCTM.

Bingham, A. (2004). Çocuklarda problem çözme yeteneklerinin geliştirilmesi (Developing problem solving skills in children) (A. $F$ Oğuzkan, Çev. [Trans.]). İstanbul: Millî Eğitim Basımevi.

Crisp, Geoffrey., Guardia, Lourdes., \& Hillier, Mathew. (2016). Using e-assessment to enhance student learning and evidence learning outcome. International Journal of Educational Technology in Higher Education.

Depdiknas. (2003). Pengembangan silabus dan penilaian mata pelajaran matematika. Jakarta.

Donato., Ruben., Menchaca., Martha., \& Valencia, Richard R. (1991). Segregation, desegregation, and integration of chicano students: Problems and prospects. In Richard R. Valencia (ed.), Chicano School Failure and Success: Research and Policy Agendas for the 
1990s, 27-58.

Duong, M. Q. (2016). The effects of academic learning on problem-solving efficacy of vietnamese university students: a case study of Vietnam National University-Ho Chi Minh City. Educare. 5(2), 161-172.

Duman, B. (2013). Problem çözme ve problem çözme terminolojisi (Problem solving and problemsolving terminology). Ocak, G. (Ed.), Ögretim Illke ve yöntemleri içinde (Chapter in teaching principles and methods). Ankara: Pegem Akademi Yayınlarl. pp. 415423

Heruman. (2007). Model pembelajaran matematika di sekolah dasar. Bandung: PT Remaja Rosdakarya.

Hodgman, Matthew. (2014). Using authentic assessments to better facilitateteaching and learning. The Case for Student Portfolios. 4(3), 59-65.

Santrock, John W. (2008). Psikologi pendidikan. Jakarta: Prenada Media Group.

Lohman \& Finkelstein. (2002). Designing cased in problem learning to foster problem-solving skill. Research in Dental Education Jurnal. 6 (1), 121-127.

Liberna, Hawa. (2012). Peningkatan kemampuan berpikir kritis matematis siswa melalui penggunaan metode improve pada materi sistem persamaan linear dua variabel. Formatif : Jurnal Ilmiah Pendidikan MIPA. 3(2).

Nurhadi, (2004). Pembelajaran Kontekstual dan penerapannya dalam KBK. Malang: UM Press.

Obodo, G.C. (2004). Principles and practice of mathematics education in Nigeria. Enugu: The Floxtone Press.

Putri, S. Kynanda., Hasratuddin., \& Syahputra, Edi. (2019). Development of learning devices based on realistic mathematics education to improve students' spatial ability and motivation. International Electronic Journal Of Mathematics Education. 14(2), 393400.

Romberg, T. A., \& Wilson, L. D. (1995). Issues related to the development of an authentic assessment system for school mathematics. In T. A. Romberg (Ed.), Reform in school mathematics and authentic assessment. New York: State University of New York. (pp.19-37).

Siswantara, Manuaba \& Meter (2013). Penerapan Model Problem Based Learning (PBL) Untuk Meningkatkan Aktivitas dan Hasil Belajar IPA Siswa Kelas IV SD Negeri 8 Kesiman. Jurnal Garuda Portal. (1), 1-10.

Surya, Edy; Putri, Feria Andriana, \& Mukhtar. (2017). Improving mathematical problem-solving ability and self-confidence of high school students through contextual learning model. Journal on Mathematics Education. 8(1), p85-94.

Tabatabaei, O., \& Assefi, F. (2012). The effect of portfolio assessment technique on writing performance of EFL learners. English Language Teaching. 5(5), 138. https://doi.org/10.5539/elt.v5n5p138

Toraman, Çetin., Şenol, Orakcı., \& Osman, Aktan. (2020). Analysis of the relationships between mathematics achievement, reflective thinking of problem solving and metacognitive awareness. International Journal of Progressive Education. 16(2).

Trianto (2009).Mendesain Model Pembelajaran Inovatif Progresif. Surabaya: Kencana.

Wulandari, Budi \& Suryandari. (2013). Penerapan model pbl (problem based learning) pada pembelajaran IPA siswa kelas V SD. Jurnal Kalam Cendekiawan PGSD Kebumen. 1, 13-17. 